\title{
Kajian Kinerja Struktur Gedung Simetris Menggunakan Peredam Tipe Fluid Viscous Damper
}

\author{
Nur Laeli Hajati dan Ardita Narabuana Hanif \\ Jurusan Teknik Sipil, Fakultas Teknik Sipil dan Perencanaan, ITENAS, Bandung \\ Email: eli10871@gmail.com
}

\begin{abstract}
ABSTRAK
Desain struktur gedung harus memenuhi 3 (tiga) aspek utama; yaitu: kekuatan, kekakuan, dan daktilitas. Salah satu upaya untuk meningkatkan kinerja struktur gedung dalam kondisi pembebanan dinamis (beban gempa, beban angin, beban getaran mesin) adalah meredam getaran dengan memasang sistem kontrol pasif berupa fluid viscous damper $(F V D)$. Tujuan penelitian ini adalah untuk mengetahui keefektifan pola penempatan FVD pada struktur gedung bertingkat beton bertulang tipe SPRMK menggunakan jenis FVD yang sama dengan mencermati kinerja struktur meliputi aspek waktu getar struktur, gaya geser dasar, simpangan antar tingkat, serta tingkat kinerja struktur. Analisis struktur dilakukan sampai tahap analisis beban dorong dengan bantuan perangkat lunak ETABS v.2016. Hasil penelitian menunjukkan bahwa Pola-4 dengan formasi FVD berada pada seluruh area bentang tengah portal interior pada potongan melintang dan pada seluruh area bentang tengah 2 portal interior pada potongan memanjang memberikan kinerja struktur yang semakin baik berdasarkan aspek waktu getar struktur, gaya geser dasar, simpangan antar tingkat, daktilitas, tingkat kinerja struktur, dan daktilitas,
\end{abstract}

Kata kunci: fluid viscous damper, waktu getar struktur, simpangan antar tingkat, tingkat kinerja struktur, daktilitas.

\begin{abstract}
The structure design must fulfil 3 main aspects, there are: strength, stiffness, and ductility. One of effort to increase performance of structure in dynamic's load (earthquake force, wind force, vibration machine) is to damp vibration by installing passive control system in form fluid viscous damper (FVD). The purpose of this study to determine effectiveness of FVD placement pattern on SPRMK concrete building stucture using the same type of FVD by observing the performance of structures covering aspects of period of structure, base shear, drift, and level performance of the structure. Structural analysis is carried out to stage push-over analysis with software ETABS v.2016. The result of this reserch is Pola-4 with FVD formation is located in the entire middle span of the interior portal on the cross section and the entire middle span of the interior portal on the longitudinal section give structural performance better assessed by aspects of the period of structure, base shear, drift, level performance of the structure, and ductility.
\end{abstract}

Keywords: fluid viscous damper, period, drift, level of performance structure, ductility. 


\section{PENDAHULUAN}

Desain struktur gedung harus memenuhi 3 (tiga) aspek utama; yaitu: kekuatan, kekakuan, dan daktilitas. Hal ini bermakna bahwa kinerja struktur sedemikian rupa sehingga saat struktur dan elemen struktur mengalami pembebanan termasuk beban dinamis (beban gempa, beban angin, beban getaran mesin) tidak terjadi tegangan dan deformasi melebihi nilai izin; serta struktur dalam kondisi daktail, halmana struktur atau komponennya masih mampu untuk melakukan deformasi inelastis besar secara bolakbalik dan berulang yang menyebabkan terjadinya pelelehan pertama sambil mempertahankan kekuatan dan kekakuan yang cukup, sehingga struktur tersebut tetap berdiri walaupun sudah berada dalam kondisi diambang keruntuhan.

Salah satu upaya untuk meningkatkan kinerja struktur gedung dalam kondisi pembebanan dinamis (beban gempa, beban angin, beban getaran mesin) adalah meredam getaran dengan memasang sistem kontrol pasif berupa fluid viscous damper (FVD). Tujuan pemasangan FVD adalah untuk mereduksi defleksi lateral dan mereduksi simpangan antar tingkat [6], mendisipasi (melepaskan) energi beban dinamis [3]. Penelitian ini dilakukan bertujuan untuk mengetahui keefektifan pola penempatan FVD pada struktur gedung bertingkat beton bertulang tipe SPRMK menggunakan jenis FVD yang sama dengan mencermati kinerja struktur meliputi aspek waktu getar struktur, gaya geser dasar, simpangan antar tingkat, tingkat kinerja struktur, dan tingkat daktilitas. Analisis struktur dilakukan sampai tahap push-over analysis dengan bantuan perangkat lunak ETABS v.2016.

\section{TINJAUAN PUSTAKA}

\subsection{Fluid Viscous Damper dan Disipasi Energi}

Fluid viscous damper $(F V D)$ adalah suatu alat yang digunakan untuk meredam sebuah gaya dinamis yang bekerja pada sebuah struktur seperti beban gempa, beban angin, dan beban getaran mesin. FVD berfungsi sebagai peredam tambahan pada struktur dengan mereduksi tegangan dan defleksi saat pembebanan terjadi [9] serta mereduksi gaya saat pembebanan terjadi [4].

Peredam FVD menghilangkan energi dengan mengubah energi kinetik menjadi energi panas, selanjutnya panas yang terjadi menghilang di udara (atmosfir) [9]. Jika piston FVD tertekan, fluida mengalir dari Chamber 2 (Ruang 2) ke Chamber 1 (Ruang 1), sebaliknya jika piston FVD tertarik, maka fluida mengalir dari Chamber 1 ke Chamber 2. Perbedaan tekanan yang besar yang melewati orifice menciptakan sebuah gaya redaman. Skema potongan memanjang FVD dapat dilihat pada Gambar 1.

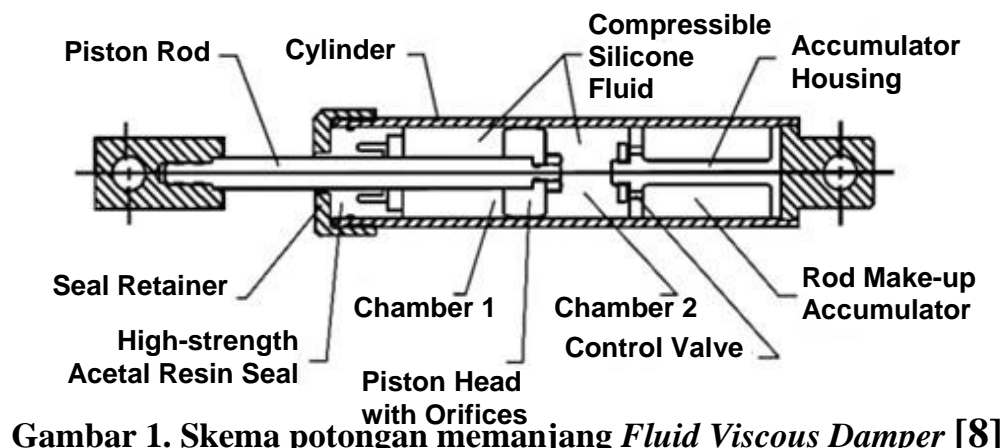

Disipasi energi gempa terjadi sesuai dengan konsep hubungan energi bergantung dalam fungsi waktu ( $t$ ) seperti pada Persamaan 1 berikut [5].

$$
E(t)=E_{k}(t)+E_{s}(t)+E_{h}(t)+E_{d}(t)
$$

halmana:

$E$ = input energi absolut dari pergerakan gempa, 
$E_{k}=$ energi kinetik absolut,

$E_{S}=$ energi regangan elastis pemulihan (recoverable),

$E_{h}=$ disipasi energi irrecoverable oleh sistem struktur melalui fase inelastis atau bentuk lain (viscous dan histeretis),

$E_{d}=$ disipasi energi melalui peredam tambahan,

$t=$ merepresentasikan fungsi waktu.

\subsection{Kekakuan pada Fluid Viscous Damper}

Kekakuan dari fluid viscous dampers seperti diuraikan dalam Persamaan 2 berikut [8].

$$
K=\frac{A E}{L}
$$

halmana:

$K=$ kekakuan fluid viscous damper $\left[\frac{\mathrm{kg}}{\mathrm{m}}\right]$,

$A=$ luas selimut fluid viscous damper $\left[\mathrm{m}^{2}\right]$,

$E=$ modulus elastisitas penampang $\left[\frac{\mathrm{kg}}{\mathrm{m}^{2}}\right]$,

$L=$ panjang fluid viscous damper $[\mathrm{m}]$.

\subsection{Gaya pada Fluid Viscous Damper}

Bentuk umum dari gaya redaman yang diinput untuk analisis struktur yang menggunakan fluid viscous damper diuraikan dalam Persamaan 3 berikut [2].

$$
F_{d}=C \dot{x}^{\alpha}
$$

halmana,

$F_{d}=$ gaya peredam $[\mathrm{kg}]$,

$C=$ konstanta peredam $\left[\mathrm{kg} \frac{\mathrm{m}}{\mathrm{s}}\right]$,

$\dot{x}=$ kecepatan dari ujung ke ujung elemen $\left[\frac{\mathrm{m}}{\mathrm{s}}\right]$,

$\alpha=$ koefisien kecepatan peredam.

Koefisien $\alpha$ merupakan eksponen yang memiliki nilai spesifik dalam rentang 0,3 sampai 1,0 . Rentang nilai $\alpha$ untuk bangunan dengan desain seismik adalah 0,4 sampai 0,5 . Peredam dengan koefisien $\alpha=1$ disebut peredam linier, sebaliknya dengan $\alpha>1$ dan $\alpha<1$ disebut peredam non-linier.

\subsection{Persamaan Diferensial Gerak Teredam}

Dengan adanya peredam berupa VFD, redaman yang bekerja pada struktur terdiri atas redaman struktur dan redaman tambahan dari FVD. Persamaan gerak untuk sistem MDOF (Multi Degree of Freedom) dengan adanya FVD diuraikan pada Persamaan 4 berikut [5].

$$
[M] . \ddot{U}+[C] \cdot \dot{U}+[K] \cdot U+F_{d}(t)=-[M] \ddot{x_{g}}
$$

halmana:

$M \quad=$ massa struktur,

$C=$ koefisien redaman struktur,

$K=$ kekakuan ekivalen struktur,

$F_{d}(t)=$ gaya peredam oleh fluid viscous damper,

$\ddot{U} \quad=$ vektor percepatan struktur,

$\dot{U} \quad=$ vektor kecepatan struktur,

$U=$ vektor perpindahan struktur,

$\ddot{x_{g}} \quad=$ ground acceleration $=$ percepatan gempa . 
Model matematis MDOF dengan FVD digambarkan seperti tertera pada Gambar 2 berikut.

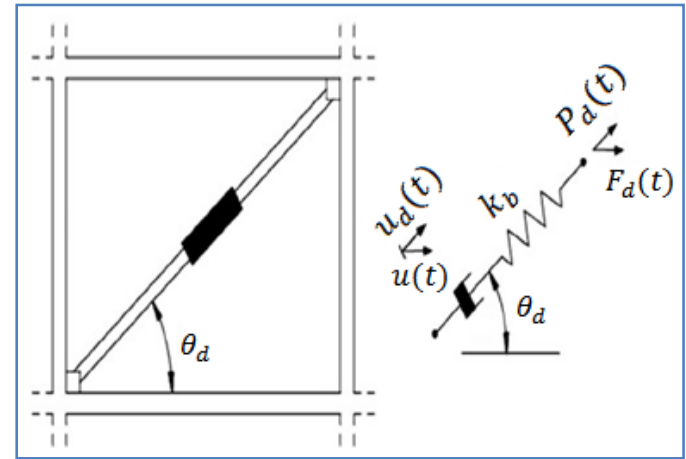

Gambar 2. Model matematis MDOF dengan FVD [5]

\subsection{Tingkat Kinerja Struktur}

Pada Gambar 3 ATC-40 (1996) memaparkan secara garis besar 4 kriteria dalam batasan tingkat kinerja struktur, yaitu:

1. Operational, merupakan kondisi dimana dapat diindikasikan tidak ada kerusakan struktural maupun non-struktural yang berarti pada struktur.

2. Immediate Occupancy (IO) merupakan kondisi dimana diindikasikan tidak ada kerusakan berarti pada struktur. Kekuatan dan kekakuan struktur kira-kira sama dengan kondisi sebelum terjadi gempa bumi. Komponen non-struktural masih berada pada tempatnya dan sebagian besar masih berfungsi jika utilitasnya masih ada. Bangunan tetap dapat berfungsi tanpa terganggu masalah perbaikan.

3. Life Safety (LS) merupakan kondisi dimana diindikasikan telah terjadi kerusakan pada elemen struktur tetapi masih bersifat daktail. Komponen non-struktural masih ada tetapi sudah tidak berfungsi. Bangunan bisa digunakan kembali setelah perbaikan.

4. Collapse Prevention (CP) merupakan kondisi dimana diindikasikan telah terjadi kerusakan pada elemen struktural dan non-struktural. Bangunan hampir runtuh dan sudah tidak dapat digunakan kembali.

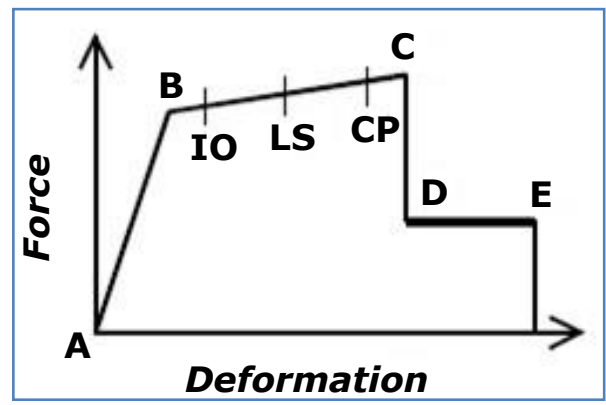

Gambar 3. Kurva deformasi terhadap gaya pada sendi plastis melalui push-over analysis [1] dan [7] 


\section{METODOLOGI PENELITIAN}

Garis besar langkah-langkah penelitian ini disajikan dalam Gambar 4 berikut.

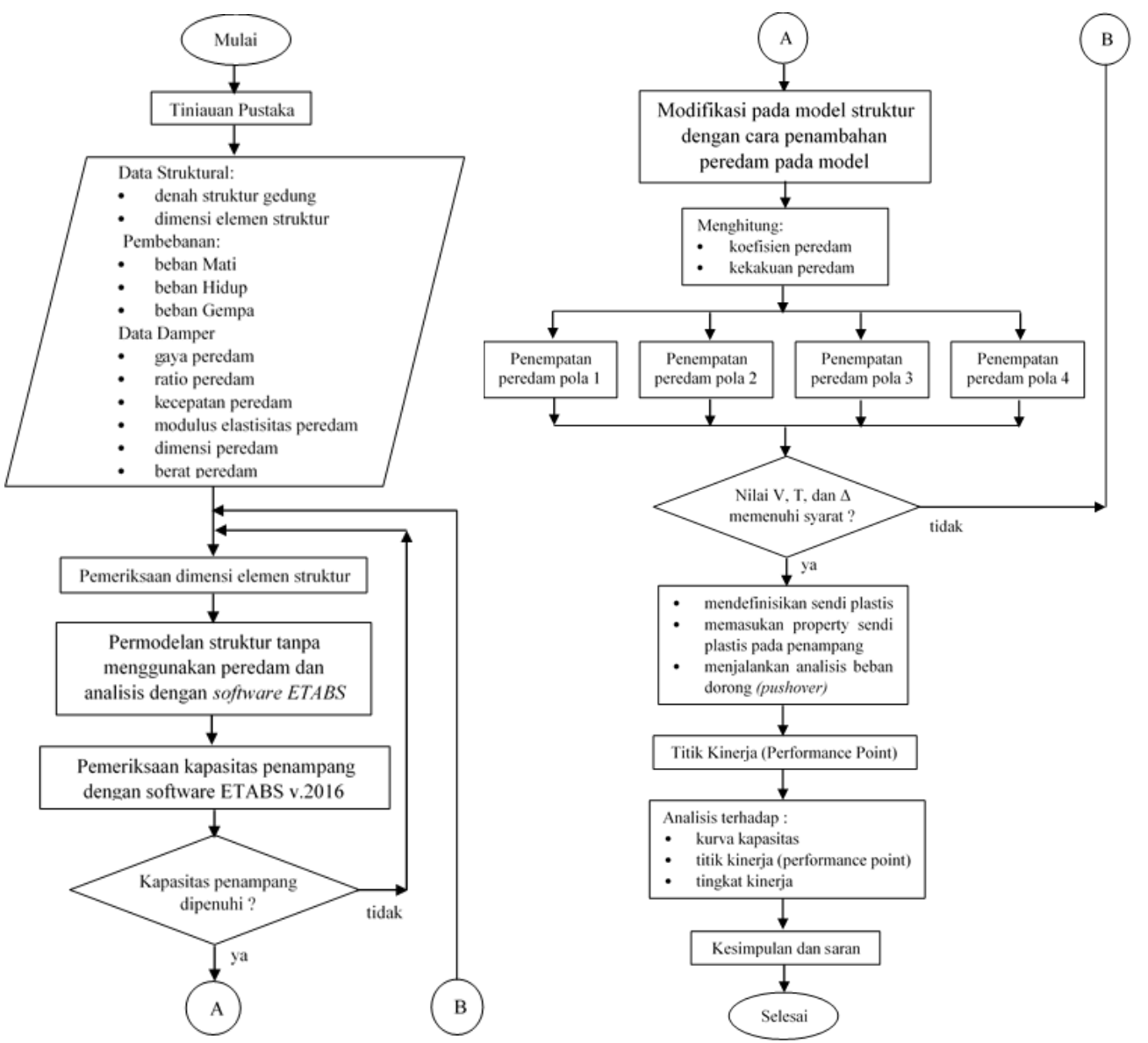

Gambar 4. Bagan alir penelitian

Analisis model struktur dilakukan dalam 2 (dua) tahap; yaitu: analisis struktur pada tahap pertama berupa analisis dinamis menggunakan respon spektrum dengan tingkat resiko kegempaan tinggi, analisis pada tahap kedua berupa analisis statik non-linier dengan metode analisis beban dorong (pushover analysis). Struktur dimodelkan dalam 4 (empat) variasi berdasarkan pola penempatan peredam FVD dan 1 (satu) model struktur tanpa peredam sebagai pembanding dalam aspek kinerja struktur. Aspek kinerja struktur yang dicermati adalah waktu getar struktur, gaya geser dasar struktur, simpangan antar tingkat, tingkat kinerja struktur, dan nilai daktilitas.

\section{KAJIAN KONFIGURASI PEREDAM FVD DAN PEMODELAN STRUKTUR}

Ruang lingkup model struktur secara umum adalah sbb.:
1. Jumlah lantai gedung
: 10 lantai.
2. Tipe struktur
portal sistem terbuka SPRMK.
3. Material struktur
beton bertulang dengan mutu beton $f_{c}^{\prime}=35 \mathrm{MPa}$.
4. Dimensi penampang melintang elemen struktur:

kolom: $500 \mathrm{~mm} * 900 \mathrm{~mm}$, balok: $400 \mathrm{~mm} * 600 \mathrm{~mm}$,

5. Tebal pelat lantai $\quad: 150 \mathrm{~mm}$.

6. Mutu baja tulangan longitudinal : $f_{y}=400 \mathrm{MPa}$.

7. Mutu baja sengkang : $f_{y}=240 \mathrm{MPa}$.

Spesifikasi fluid viscous damper FVD-1500 adalah sbb.:

1. Diameter $(d) \quad: 0,245 \mathrm{~m}$.

2. Berat (weight) : $306 \mathrm{~kg}$. 
3. Gaya redaman $\left(F_{d}\right) \quad: \quad 1.500 \mathrm{kN}=150.000 \mathrm{~kg}$.

4. Kecepatan dari ujung ke ujung elemen $(\dot{x}): 1,2 \frac{\mathrm{m}}{\mathrm{s}}$.

5. Koefisien kecepatan peredam redaman $(\alpha): 0,45$.

6. Modulus elastisitas $(E) \quad: \quad 2 * 10^{10} \frac{\mathrm{kg}}{\mathrm{m}^{2}}$.

Model struktur dibuat dalam 5 variasi berdasarkan peluang terjadinya deformasi lateral dalam 2 arah sumbu (sumbu $X$ dan sumbu $Y$ ) sebagai berikut (perhatikan Gambar 5):

1. Tanpa FVD: struktur gedung tanpa menggunakan peredam FVD (Gambar 6).

2. Pola-1: struktur gedung menggunakan peredam FVD yang ditempatkan pada portal sumbu-E dan portal sumbu-I (Gambar 7).

3. Pola-2: struktur gedung menggunakan peredam FVD yang ditempatkan pada portal sumbu-A, portal sumbu-E, portal sumbu-I dan portal sumbu-L (Gambar 8).

4. Pola-3: struktur gedung menggunakan peredam FVD yang ditempatkan pada portal sumbu-A, portal sumbu-L, portal sumbu-2 dan portal sumbu-3 (Gambar 9).

5. Pola-4: struktur gedung menggunakan peredam FVD yang ditempatkan pada portal sumbu-E, portal sumbu-I, portal sumbu-2 dan portal sumbu-3 (Gambar 10).

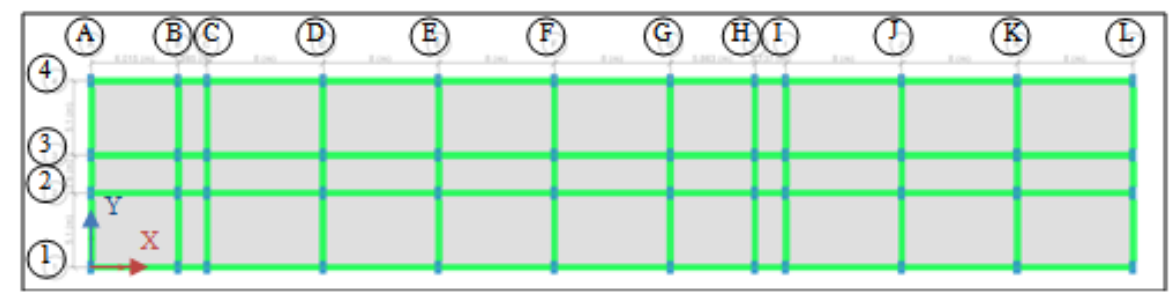

Gambar 5. Denah struktur gedung

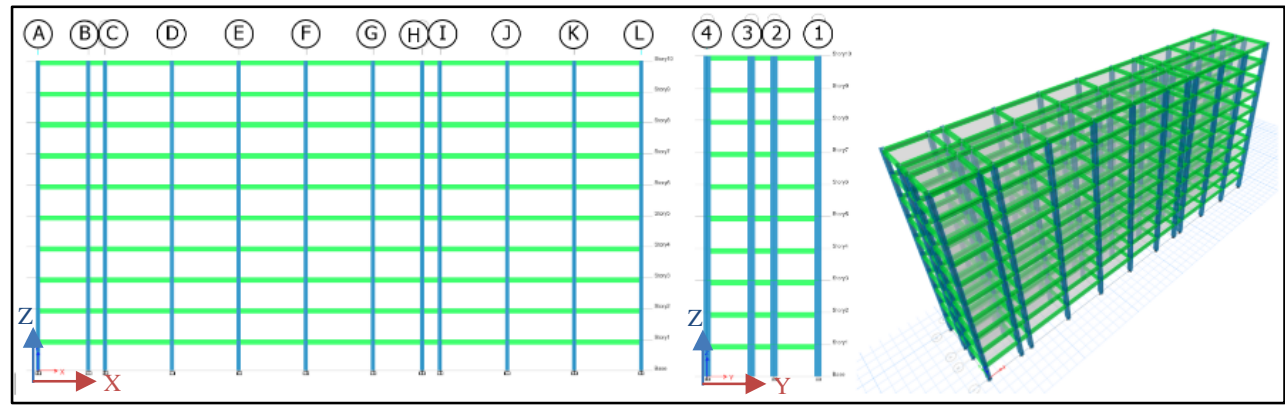
a. Tampak depan
b. Tampak samping
c. Tampak 3D

Gambar 6. Pemodelan struktur untuk Tanpa FVD

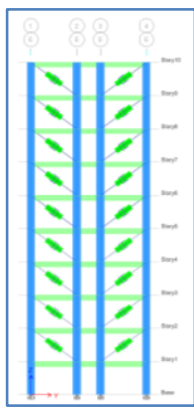

a. Potongan E-E

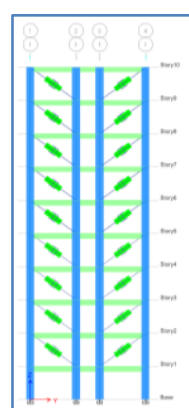

b. Potongan I-I

Gambar 7. Pemodelan struktur untuk Pola-1 


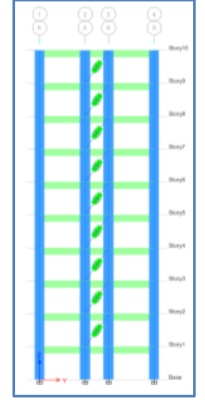

a. Potongan A-A b. Potongan E-E

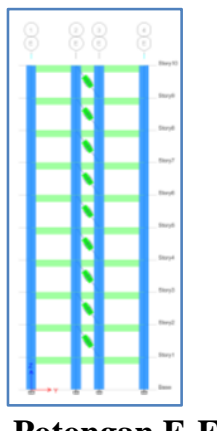

Gambar 8. Pemodelan

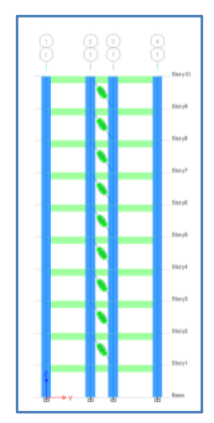

c. Potongan I-I

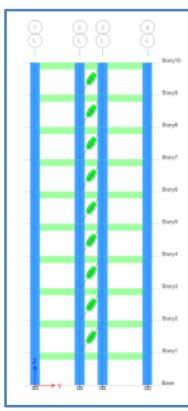

d. Potongan L-L

\section{ola-2}

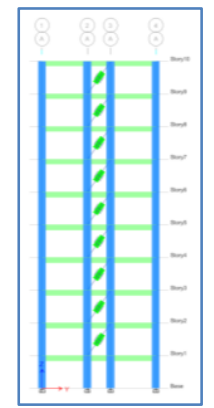

a. Potongan A-A

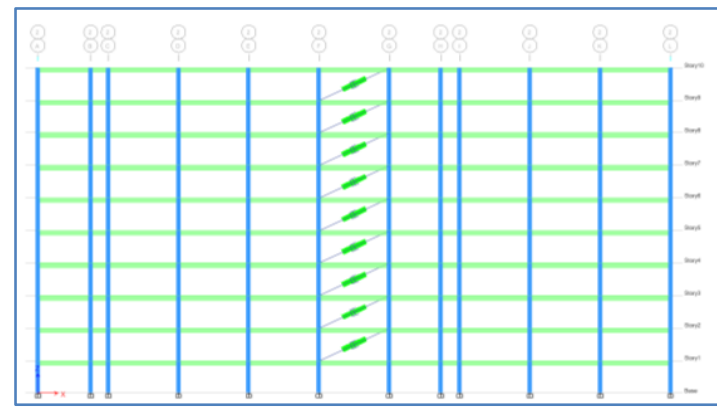

b. Potongan 2-2

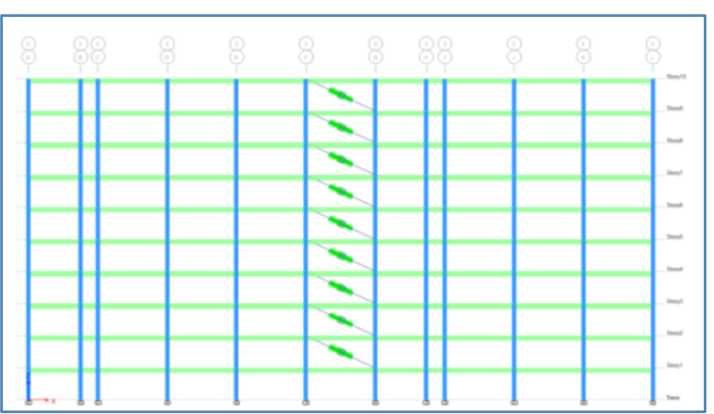

d. Potongan 3-3

c. Potongan L-L

Gambar 9. Pemodelan struktur untuk Pola-3

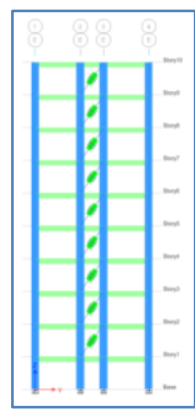

a. Potongan E-E

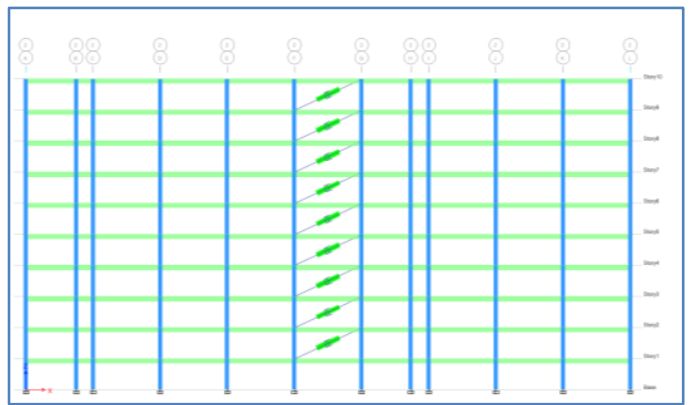

b. Potongan 2-2 


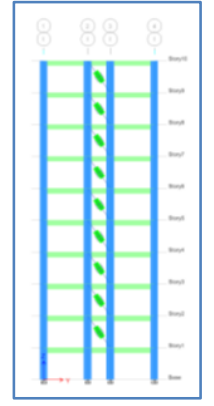

c. Potongan I-I

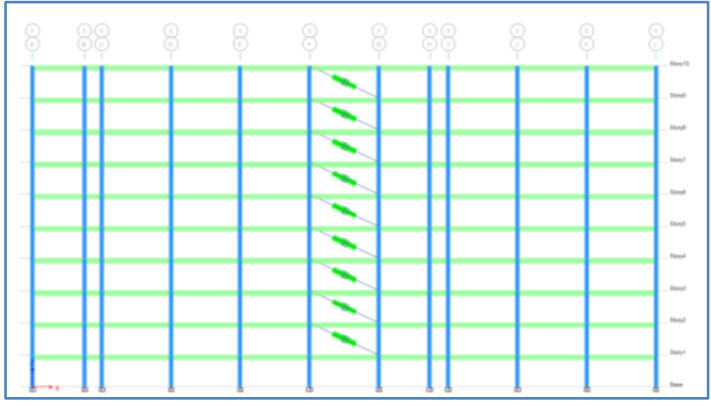

d. Potongan 3-3

Gambar 10. Pemodelan struktur untuk Pola-4

\subsection{Waktu Getar Struktur}

\section{KAJIAN KINERJA}

Tabel 1 berikut menunjukkan nilai waktu getar struktur kelima model struktur pada arah UX dan UY. Pada Tabel 1 terlihat bahwa untuk konfigurasi pemasangan FVD dalam 2 arah sumbu, pada arah $Y$ Pola-4 memiliki durasi terbesar, hal ini karena pengaruh kinerja FVD yang dipasang secara sentris pada area portal interior; sedangkan untuk konfigurasi pemasangan FVD dalam 1 arah sumbu saja (pada arah $Y$ ) Pola-1 dan Pola-2 memiliki durasi terbesar, hal ini menunjukkan bahwa jika semakin banyak dipasang FVD pada portal dengan arah sumbu yang sama, maka perilaku struktur menjadi lebih baik dalam menahan deformasi. Secara keseluruhan Pola-2 memiliki kinerja paing baik.

Tabel 1. Waktu Getar Struktur

\begin{tabular}{|c|c|c|c|c|c|c|}
\hline \multirow[b]{2}{*}{ Arah } & \multicolumn{5}{|c|}{ Waktu Getar Struktur [detik] } & \multirow{2}{*}{$\begin{array}{l}\text { Waktu } \\
\text { Getar Izin } \\
\text { [detik] }\end{array}$} \\
\hline & $\begin{array}{c}\text { Tanpa } \\
\text { FVD }\end{array}$ & Pola-1 & Pola-2 & Pola-3 & Pola-4 & \\
\hline UX & 1,185 & 1,185 & 1,185 & 0,937 & 0,939 & 1,682 \\
\hline UY & 0,918 & 0,720 & 0,826 & 0,832 & 0,851 & 1,682 \\
\hline
\end{tabular}

\subsection{Gaya Geser Dasar}

Tabel 2 berikut menunjukkan nilai gaya geser dasar lima jenis pemodelan struktur. Pada Tabel 2 tersebut dapat dilihat bahwa untuk konfigurasi pemasangan FVD dalam 2 arah sumbu, Pola-4 pada arah $X$ dan arah $Y$ memiliki nilai gaya geser dasar terkecil, hal ini menunjukkan bahwa dengan beban yang sama tumpuan struktur lebih mampu memikul beban, hal ini menunjukkan bahwa formasi gaya redaman yang sentris (berpusat pada inti gedung) lebih baik dibandingkan dengan formasi gaya redaman yang berada pada "selimut" gedung. Pada Tabel 2 juga dapat dilihat bahwa untuk konfigurasi pemasangan FVD dalam 1 arah sumbu, nilai gaya geser dasar pada Pola-1 terkecil dan nilai gaya geser arah $X$ untuk Pola-2 lebih kecil dibandingkan nilai gaya geser dasar arah $Y$ untuk Pola-1 dan Pola-2, hal ini menunjukkan bahwa jika semakin banyak dipasang FVD pada portal dengan arah sumbu yang sama, maka tumpuan struktur menjadi lebih baik dalam menahan beban. Secara umum Pola-1 lebih baik.

Tabel 2. Gaya Geser Dasar

\begin{tabular}{cccccc}
\hline Jenis & \multicolumn{5}{c}{ Gaya Geser Dasar $[\mathrm{kN}]$} \\
\cline { 2 - 6 } $\begin{array}{c}\text { Gaya Geser } \\
\text { Dasar }\end{array}$ & $\begin{array}{c}\text { Tanpa } \\
\text { FVD }\end{array}$ & Pola-1 & Pola-2 & Pola-3 & Pola-4 \\
\hline FX & $\mathbf{9 . 8 8 9 , 6 7}$ & $\mathbf{9 . 8 9 2 , 7 2}$ & $9.901,08$ & $12.511,07$ & $\mathbf{1 2 . 4 8 4 , 4 3}$ \\
\hline FY & $\mathbf{1 2 . 7 6 6 , 0 8}$ & $16.281,77$ & $14.192,34$ & $14.089,99$ & $\mathbf{1 3 . 7 7 5 , 4 1}$ \\
\hline
\end{tabular}




\subsection{Simpangan Antar Tingkat (Drift)}

Tabel 3 dan Tabel 4 berikut menunjukkan nilai simpangan antar tingkat dari lima jenis pemodelan struktur. Dari nilai-nilai simpangan antar tingkat pada Tabel 3 dan Tabel 4 dapat dicermati bahwa defleksi horizontal arah $X$ akan berkurang jika FVD dipasang pada portal sumbu interior dan sumbu eksterior dengan jumlah FVD pada arah $X$ lebih banyak (kasus Pola-3), dan defleksi horizontal arah $Y$ akan berkurang dengan cukup memasang FVD pada portal eksterior arah $Y$. Secara umum Pola-1 lebih baik.

Tabel 3. Simpangan Antar Tingkat Arah UX

\begin{tabular}{ccccccc}
\hline \multirow{2}{*}{ Lantai } & \multicolumn{3}{c}{ Nilai Simpangan Antar Tingkat [mm] } & Simpangan Antar Tingkat \\
\cline { 2 - 6 } & $\begin{array}{c}\text { Tanpa } \\
\text { FVD }\end{array}$ & Pola-1 & Pola-2 & Pola-3 & Pola-4 & Izin \\
[mm]
\end{tabular}

\subsection{Keruntuhan Struktur}

Tahapan keruntuhan untuk semua model sruktur pada arah UX dan UY ditampilkan pada Tabel 5 s.d. Tabel 14 berikut. Berdasarkan riwayat terjadinya sendi plastis (SP) untuk Pola-1 s.d. Pola-4, pada fase B ke C terjadi SP pada semua pola (8 SP di step $1 X$ dan 2 SP di step $1 Y$ ), pada fase IO ke LS terjadi SP pada Pola-2, Pola-3, dan Pola-4 dengan paling banyak pada Pola-4 (44 SP di step 3X), pada fase LS ke CP terjadi SP pada Pola-4 (8 SP di step $4 X$ ), pada fase >CP paling banyak terjadi SP pada Pola-4 (14 SP di step $2 X$ ), pada fase $>\mathbf{E}$ terjadi paling banyak SP pada Pola-4 (14 SP di step $2 X$ ). Hal ini menunjukkan bahwa Pola-1 paling lambat memulai terjadinya sendi plastis dan Pola-4 mendisipasi energi gempa terbesar dibandingkan 3 pola lainnya.

Tabel 5. Distribusi Sendi Plastis Struktur Tanpa FVD Arah UX

\begin{tabular}{ccccccccccccc}
\hline Step & $\begin{array}{c}\text { Displacement } \\
{[\mathbf{m m}]}\end{array}$ & $\begin{array}{c}\text { Base Force } \\
{[\mathbf{k N}]}\end{array}$ & A-B & B-C & C-D & D-E & $>$ E & A-IO & IO-LS & LS-CP & $>$ CP & Total \\
\hline 0 & 0 & 0 & 5.120 & 0 & 0 & 0 & 0 & 5.120 & 0 & 0 & 0 & 5.120 \\
\hline 1 & 23,485 & $3.915,841$ & 5.116 & 4 & 0 & 0 & 0 & 5.120 & 0 & 0 & 0 & 5.120 \\
\hline 2 & 116,603 & $14.260,982$ & 3.984 & 1.136 & 0 & 0 & 0 & 5.120 & 0 & 0 & 0 & 5.120 \\
\hline 3 & 187,277 & $18.378,644$ & 3.648 & 1.472 & 0 & 0 & 0 & 5.108 & 0 & 0 & 12 & 5.120 \\
\hline
\end{tabular}


Tabel 6. Distribusi Sendi Plastis Struktur Tanpa FVD Arah UY

\begin{tabular}{ccccccccccccc}
\hline Step & $\begin{array}{c}\text { Displacement } \\
{[\mathbf{m m}]}\end{array}$ & $\begin{array}{c}\text { Base Force } \\
{[\mathbf{k N}]}\end{array}$ & $\mathbf{A}-\mathbf{B}$ & $\mathbf{B}-\mathbf{C}$ & $\mathbf{C}-\mathbf{D}$ & $\mathbf{D}-\mathbf{E}$ & $>\mathbf{E}$ & A-IO & IO-LS & LS-CP & $>$ CP & Total \\
\hline 0 & 0 & 0 & 5.120 & 0 & 0 & 0 & 0 & 5.120 & 0 & 0 & 0 & 5.120 \\
\hline 1 & 18,320 & $4.738,800$ & 5.116 & 4 & 0 & 0 & 0 & 5.120 & 0 & 0 & 0 & 5.120 \\
\hline 2 & 111,692 & $19.950,795$ & 3.728 & 1.392 & 0 & 0 & 0 & 5.120 & 0 & 0 & 0 & 5.120 \\
\hline 3 & 129,175 & $22.347,928$ & 3.644 & 1.476 & 0 & 0 & 0 & 5.108 & 0 & 0 & 0 & 5.120 \\
\hline
\end{tabular}

Tabel 7. Distribusi Sendi Plastis Struktur Pola-1 Arah UX

\begin{tabular}{ccccccccccccc}
\hline Step & $\begin{array}{c}\text { Displacement } \\
{[\mathbf{m m}]}\end{array}$ & $\begin{array}{c}\text { Base Force } \\
{[\mathbf{k N}]}\end{array}$ & $\mathbf{A}-\mathbf{B}$ & $\mathbf{B}-\mathbf{C}$ & $\mathbf{C}-\mathbf{D}$ & $\mathbf{D}-\mathbf{E}$ & $>\mathbf{E}$ & $\mathbf{A}-\mathbf{I O}$ & $\mathbf{I O}-\mathbf{L S}$ & $\mathbf{L S}-\mathbf{C P}$ & $>$ CP & Total \\
\hline 0 & 0 & 0 & 5.120 & 0 & 0 & 0 & 0 & 5.120 & 0 & 0 & 0 & 5.120 \\
\hline 1 & 27,698 & $4.618,937$ & 5.112 & 8 & 0 & 0 & 0 & 5.120 & 0 & 0 & 0 & 5.120 \\
\hline 2 & 121,869 & $14.562,808$ & 3.928 & 1.192 & 0 & 0 & 0 & 5.120 & 0 & 0 & 0 & 5.120 \\
\hline 3 & 201,044 & $18.929,190$ & 3.620 & 1.500 & 0 & 0 & 0 & 5.108 & 0 & 0 & 12 & 5.120 \\
\hline 4 & 201,049 & $18.929,239$ & 3.620 & 1.500 & 0 & 0 & 0 & 5.108 & 0 & 0 & 12 & 5.120 \\
\hline 5 & 203,032 & $19.022,408$ & 3.616 & 1.504 & 0 & 0 & 0 & 5.108 & 0 & 0 & 12 & 5.120 \\
\hline 6 & 203,318 & $19.028,314$ & 3.616 & 1.500 & 0 & 0 & 4 & 5.104 & 0 & 0 & 16 & 5.120 \\
\hline 7 & 204,032 & $19.062,640$ & 3.616 & 1.500 & 0 & 0 & 4 & 5.104 & 0 & 0 & 16 & 5.120 \\
\hline
\end{tabular}

Tabel 8. Distribusi Sendi Plastis Struktur Pola-1 Arah UY

\begin{tabular}{ccccccccccccc}
\hline Step & $\begin{array}{c}\text { Displacement } \\
{[\mathbf{m m}]}\end{array}$ & $\begin{array}{c}\text { Base Force } \\
{[\mathbf{k N}]}\end{array}$ & $\mathbf{A}-\mathbf{B}$ & $\mathbf{B}-\mathbf{C}$ & $\mathbf{C}-\mathbf{D}$ & $\mathbf{D}-\mathbf{E}$ & $>\mathbf{E}$ & $\mathbf{A}-\mathbf{I O}$ & $\mathbf{I O}-\mathbf{L S}$ & $\mathbf{L S}-\mathbf{C P}$ & $>$ CP & Total \\
\hline 0 & 0 & 0 & 5.120 & 0 & 0 & 0 & 0 & 5.120 & 0 & 0 & 0 & 5.120 \\
\hline 1 & 19,902 & $5.148,947$ & 5.118 & 2 & 0 & 0 & 0 & 5.120 & 0 & 0 & 0 & 5.120 \\
\hline 2 & 113,208 & $20.240,470$ & 3.698 & 1.420 & 0 & 0 & 2 & 5.118 & 0 & 0 & 2 & 5.120 \\
\hline 3 & 157,437 & $25.451,117$ & 3.582 & 1.536 & 0 & 0 & 2 & 5.092 & 0 & 0 & 28 & 5.120 \\
\hline
\end{tabular}

Tabel 9. Distribusi Sendi Plastis Struktur Pola-2 Arah UX

\begin{tabular}{ccccccccccccc}
\hline Step & $\begin{array}{c}\text { Displacement } \\
{[\mathbf{m m}]}\end{array}$ & $\begin{array}{c}\text { Base Force } \\
{[\mathbf{k N}]}\end{array}$ & $\mathbf{A}-\mathbf{B}$ & $\mathbf{B}-\mathbf{C}$ & $\mathbf{C}-\mathbf{D}$ & $\mathbf{D}-\mathbf{E}$ & $>\mathbf{E}$ & A-IO & IO-LS & LS-CP & $>$ CP & Total \\
\hline 0 & 0 & 0 & 5.120 & 0 & 0 & 0 & 0 & 5.120 & 0 & 0 & 0 & 5.120 \\
\hline 1 & 27,698 & $4.618,937$ & 5.112 & 8 & 0 & 0 & 0 & 5.120 & 0 & 0 & 0 & 5.120 \\
\hline 2 & 121,869 & $14.562,808$ & 3.928 & 1.192 & 0 & 0 & 0 & 5.120 & 0 & 0 & 0 & 5.120 \\
\hline 3 & 201,044 & $18.929,190$ & 3.620 & 1.500 & 0 & 0 & 0 & 5.108 & 0 & 0 & 12 & 5.120 \\
\hline 4 & 201,049 & $18.929,239$ & 3.620 & 1.500 & 0 & 0 & 0 & 5.108 & 0 & 0 & 12 & 5.120 \\
\hline 5 & 224,327 & $20.000,546$ & 3.568 & 1.552 & 0 & 0 & 0 & 5.100 & 8 & 0 & 12 & 5.120 \\
\hline
\end{tabular}

Tabel 10. Distribusi Sendi Plastis Struktur Pola-2 Arah UY

\begin{tabular}{ccccccccccccc}
\hline Step & $\begin{array}{c}\text { Displacement } \\
{[\mathbf{m m}]}\end{array}$ & $\begin{array}{c}\text { Base Force } \\
{[\mathbf{k N}]}\end{array}$ & A-B & B-C & C-D & D-E & $>$ E & A-IO & IO-LS & LS-CP & $>$ CP & Total \\
\hline 0 & 0 & 0 & 5.120 & 0 & 0 & 0 & 0 & 5.120 & 0 & 0 & 0 & 5.120 \\
\hline 1 & 19,902 & $5.148,947$ & 5.118 & 2 & 0 & 0 & 0 & 5.120 & 0 & 0 & 0 & 5.120 \\
\hline 2 & 113,208 & $20.240,470$ & 3.698 & 1.420 & 0 & 0 & 2 & 5.118 & 0 & 0 & 2 & 5.120 \\
\hline 3 & 157,437 & $25.451,117$ & 3.582 & 1.536 & 0 & 0 & 2 & 5.092 & 0 & 0 & 28 & 5.120 \\
\hline
\end{tabular}

Tabel 11. Distribusi Sendi Plastis Struktur Pola ke-3 Arah UX

\begin{tabular}{ccccccccccccc}
\hline Step & $\begin{array}{c}\text { Displacement } \\
{[\mathbf{m m}]}\end{array}$ & $\begin{array}{c}\text { Base Force } \\
{[\mathbf{k N}]}\end{array}$ & A-B & B-C & C-D & D-E & $>$ E & A-IO & IO-LS & LS-CP & $>$ CP & Total \\
\hline 0 & 0 & 0 & 5.120 & 0 & 0 & 0 & 0 & 5.120 & 0 & 0 & 0 & 5.120 \\
\hline 1 & 27,698 & $4.618,937$ & 5.112 & 8 & 0 & 0 & 0 & 5.120 & 0 & 0 & 0 & 5.120 \\
\hline 2 & 121,869 & $14.562,808$ & 3.928 & 1.192 & 0 & 0 & 0 & 5.120 & 0 & 0 & 0 & 5.120 \\
\hline 3 & 201,044 & $18.929,190$ & 3.620 & 1.500 & 0 & 0 & 0 & 5.108 & 0 & 0 & 12 & 5.120 \\
\hline 4 & 201,049 & $18.929,239$ & 3.620 & 1.500 & 0 & 0 & 0 & 5.108 & 0 & 0 & 12 & 5.120 \\
\hline 5 & 223,755 & $19.974,073$ & 3.568 & 1.552 & 0 & 0 & 0 & 5.100 & 8 & 0 & 12 & 5.120 \\
\hline
\end{tabular}


Tabel 12. Distribusi Sendi Plastis Struktur Pola ke-3 Arah UY

\begin{tabular}{ccccccccccccc}
\hline Step & $\begin{array}{c}\text { Displacement } \\
{[\mathbf{m m}]}\end{array}$ & $\begin{array}{c}\text { Base Force } \\
{[\mathbf{k N}]}\end{array}$ & $\mathbf{A}-\mathbf{B}$ & $\mathbf{B}-\mathbf{C}$ & $\mathbf{C}-\mathbf{D}$ & $\mathbf{D}-\mathbf{E}$ & $\mathbf{\text { E }}$ & A-IO & IO-LS & LS-CP & $>$ CP & Total \\
\hline 0 & 0 & 0 & 5.120 & 0 & 0 & 0 & 0 & 5.120 & 0 & 0 & 0 & 5.120 \\
\hline 1 & 19,902 & $5.148,947$ & 5.118 & 2 & 0 & 0 & 0 & 5.120 & 0 & 0 & 0 & 5.120 \\
\hline 2 & 113,208 & $20.240,470$ & 3.698 & 1.420 & 0 & 0 & 2 & 5.118 & 0 & 0 & 2 & 5.120 \\
\hline 3 & 157,437 & $25.451,117$ & 3.582 & 1.536 & 0 & 0 & 2 & 5.092 & 0 & 0 & 28 & 5.120 \\
\hline
\end{tabular}

Tabel 13. Distribusi Sendi Plastis Struktur Pola-4 Arah UX

\begin{tabular}{ccccccccccccc}
\hline Step & $\begin{array}{c}\text { Displacement } \\
{[\mathbf{m m}]}\end{array}$ & $\begin{array}{c}\text { Base Force } \\
{[\mathbf{k N}]}\end{array}$ & $\mathbf{A}-\mathbf{B}$ & $\mathbf{B}-\mathbf{C}$ & $\mathbf{C}-\mathbf{D}$ & $\mathbf{D}-\mathbf{E}$ & $>\mathbf{E}$ & $\mathbf{A}-\mathbf{I O}$ & $\mathbf{I O}-\mathbf{L S}$ & $\mathbf{L S}-\mathbf{C P}$ & $>$ CP & Total \\
\hline 0 & 0 & 0 & 5.120 & 0 & 0 & 0 & 0 & 5.120 & 0 & 0 & 0 & 5.120 \\
\hline 1 & 27,698 & $4.618,937$ & 5.112 & 8 & 0 & 0 & 0 & 5.120 & 0 & 0 & 0 & 5.120 \\
\hline 2 & 121,835 & $14.564,218$ & 3.940 & 1.166 & 0 & 0 & 14 & 5.106 & 0 & 0 & 14 & 5.120 \\
\hline 3 & 215,065 & $19.706,568$ & 3.598 & 1.462 & 0 & 0 & 60 & 5.010 & 44 & 0 & 66 & 5.120 \\
\hline 4 & 245,631 & $21.131,916$ & 3.524 & 1.518 & 2 & 0 & 76 & 4.984 & 46 & 8 & 82 & 5.120 \\
\hline 5 & 245,645 & $21.132,031$ & 3.524 & 1.518 & 2 & 0 & 76 & 4.984 & 46 & 8 & 82 & 5.120 \\
\hline 6 & 248,165 & $21.235,142$ & 3.522 & 1.518 & 4 & 0 & 76 & 4.984 & 46 & 4 & 86 & 5.120 \\
\hline
\end{tabular}

Tabel 14. Distribusi Sendi Plastis Struktur Pola-4 Arah UY

\begin{tabular}{cccccccccccccc}
\hline Step & $\begin{array}{c}\text { Displacement } \\
{[\mathbf{m m}]}\end{array}$ & $\begin{array}{c}\text { Base Force } \\
{[\mathbf{k N}]}\end{array}$ & $\mathbf{A}-\mathbf{B}$ & $\mathbf{B}-\mathbf{C}$ & $\mathbf{C}-\mathbf{D}$ & $\mathbf{D}-\mathbf{E}$ & $>\mathbf{E}$ & $\mathbf{A}-\mathbf{I O}$ & $\mathbf{I O}-\mathbf{L S}$ & $\mathbf{L S}-\mathbf{C P}$ & $>$ CP & Total \\
\hline 0 & 0 & 0 & 5.120 & 0 & 0 & 0 & 0 & 5.120 & 0 & 0 & 0 & 5.120 \\
\hline 1 & 19,902 & $5.148,947$ & 5.118 & 2 & 0 & 0 & 0 & 5.120 & 0 & 0 & 0 & 5.120 \\
\hline 2 & 113,208 & $20.240,470$ & 3.698 & 1.420 & 0 & 0 & 2 & 5.118 & 0 & 0 & 2 & 5.120 \\
\hline 3 & 157,437 & $25.451,117$ & 3.582 & 1.536 & 0 & 0 & 2 & 5.092 & 0 & 0 & 28 & 5.120 \\
\hline
\end{tabular}

\subsection{Kinerja Struktur}

Grafik hubungan antara kurva kapasitas dan titik kinerja struktur Tanpa FVD ditunjukkan pada Gambar 11a dan Gambar 11b, untuk struktur dengan Pola-1 s.d. Pola-4 ditunjukkan pada Gambar 12a s.d. Gambar 15b. Kinerja struktur paling baik untuk arah $X$ ditunjukkan oleh Pola-4, sedangkan kinerja struktur paling baik untuk arah $Y$ ditunjukkan oleh Pola-1. Hal ini mengindikasikan bahwa pemasangan FVD pada arah melintang sudah cukup baik jika hanya pada portal eksterior, sedangkan untuk kasus pemasangan FVD dengan 2 arah sumbu akan lebih baik jika FVD dipasang pada portal interior.

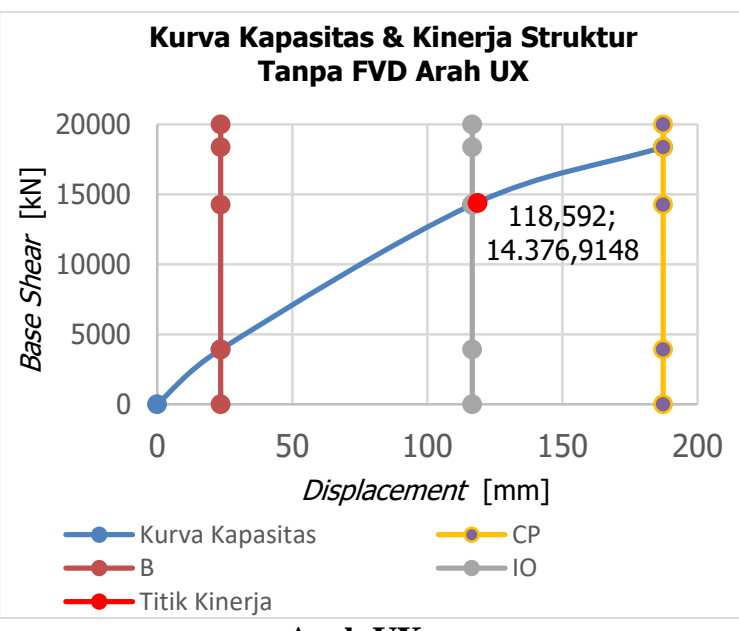

a. Arah UX

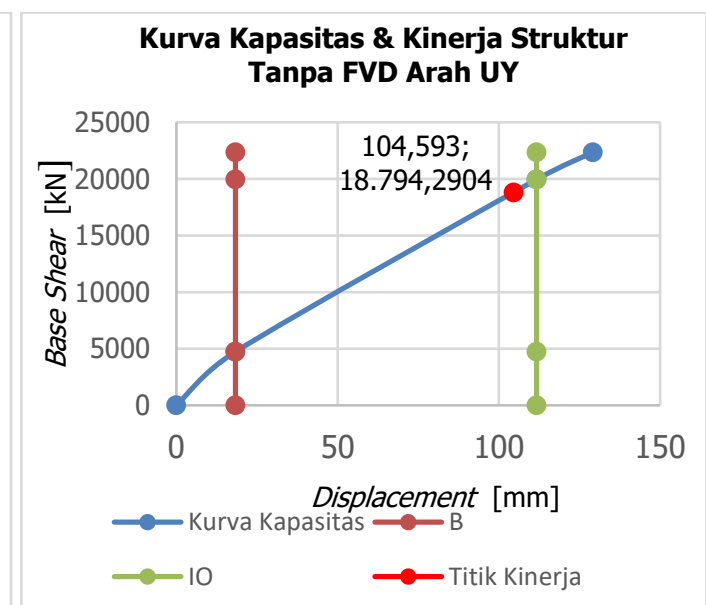

b. Arah UY

Gambar 11. Kurva kapasitas \& kinerja struktur Tanpa FVD 


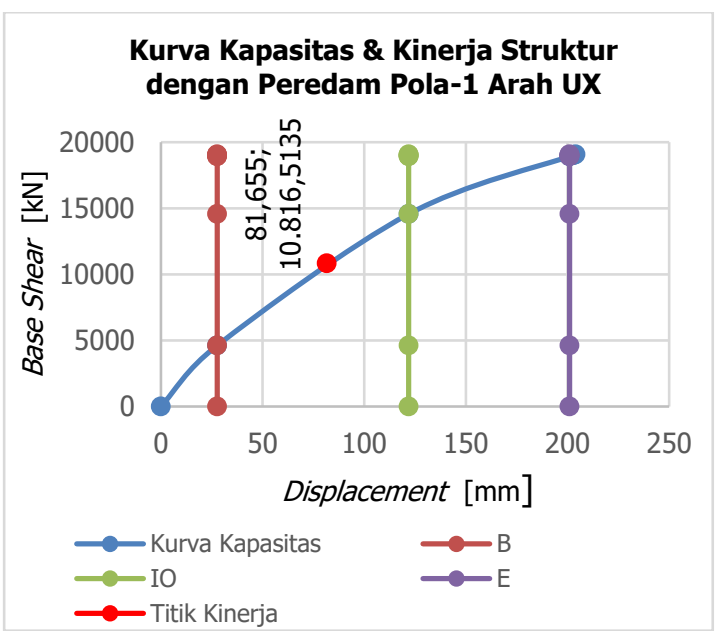

a. Arah UX

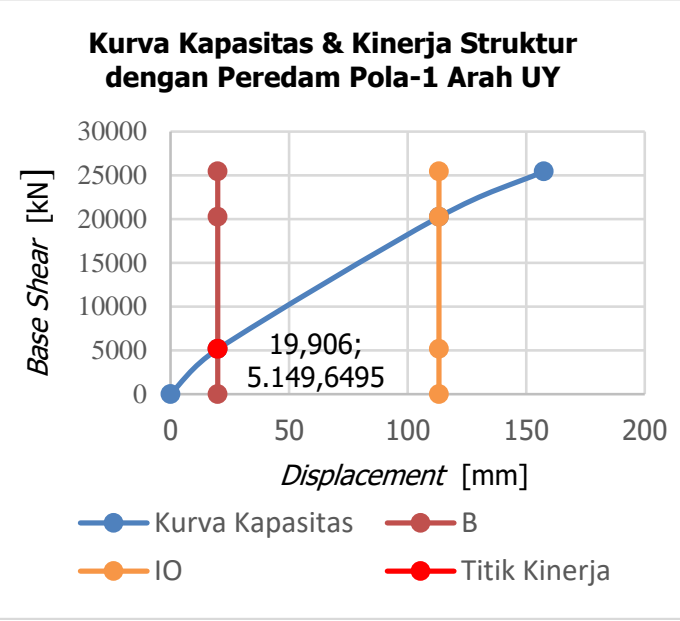

b. Arah UY

Gambar 12. Kurva kapasitas \& kinerja struktur Pola-1

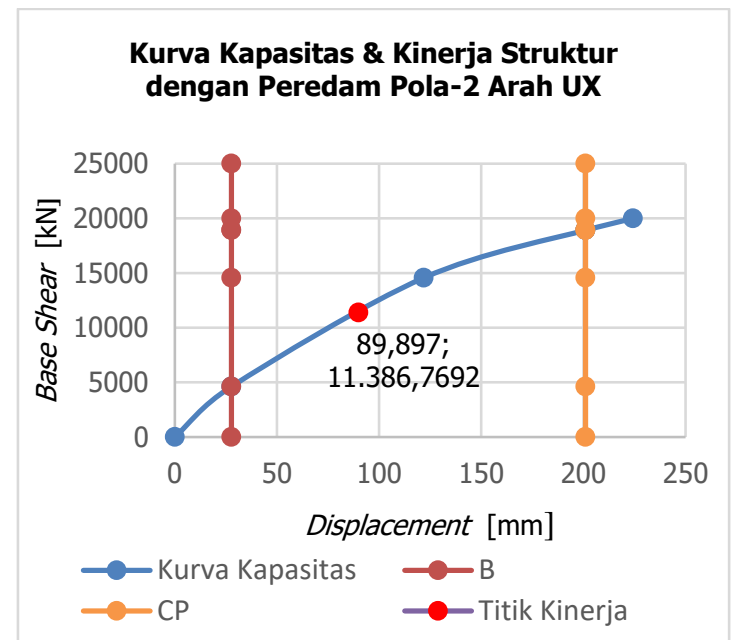

a. Arah UX

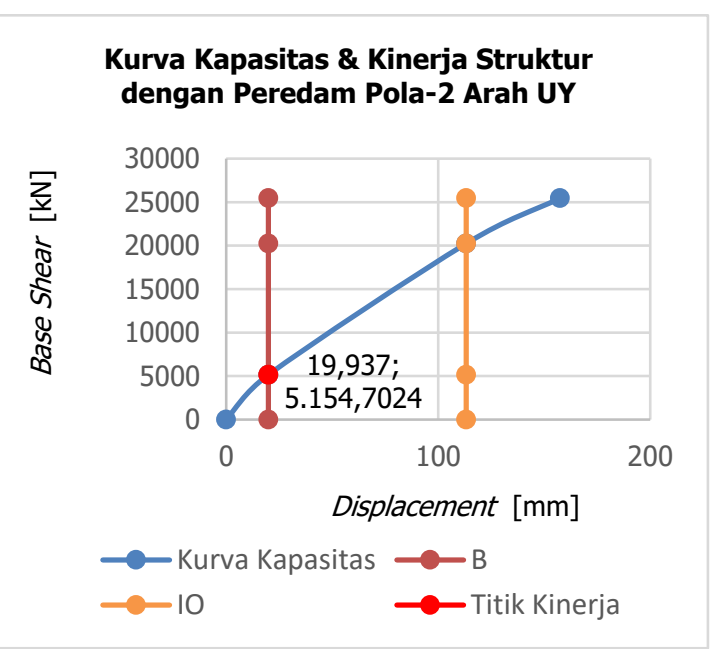

b. Arah UY

Gambar 13. Kurva kapasitas \& kinerja struktur Pola-2

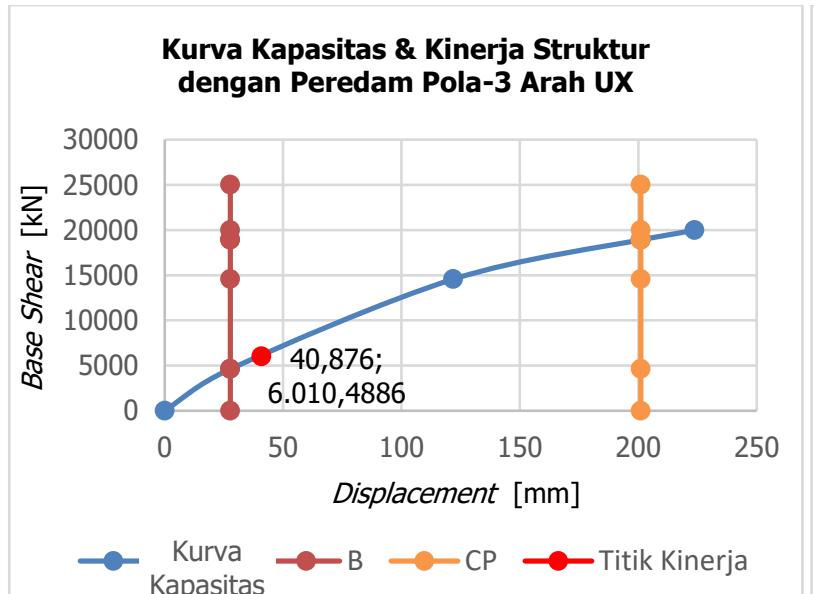

a. Arah UX

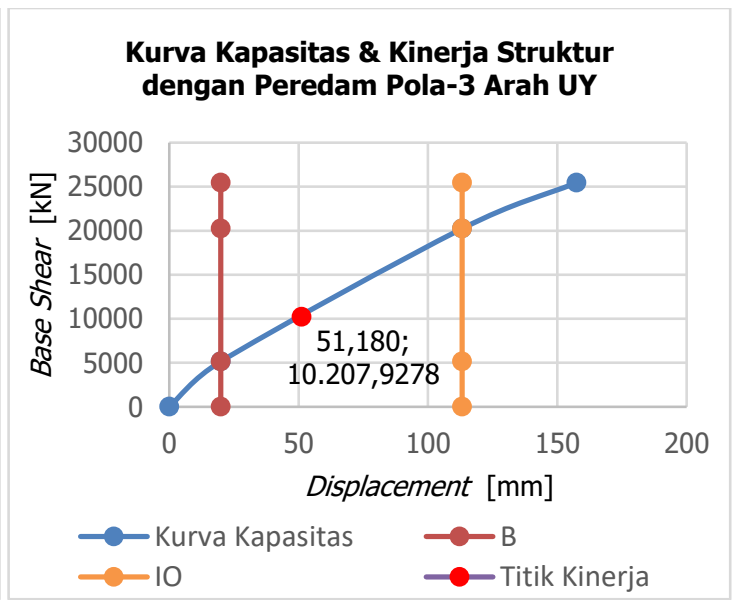

b. Arah UY

Gambar 14. Kurva kapasitas \& kinerja struktur Pola-3 


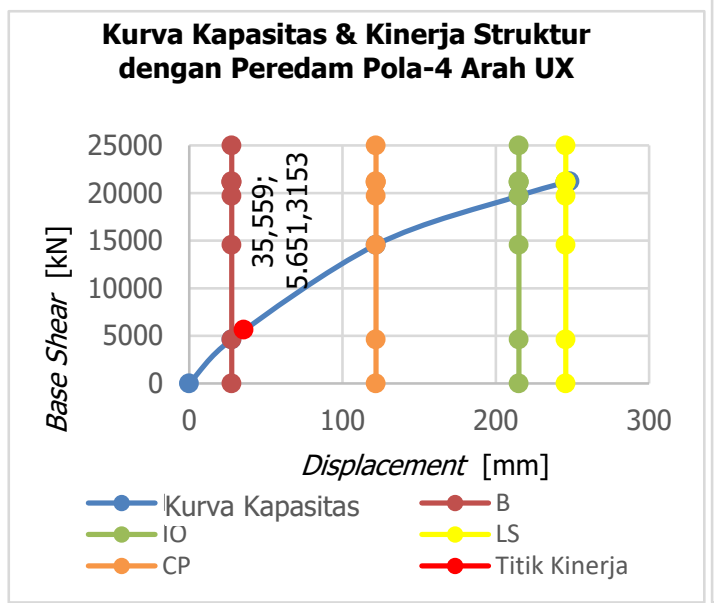

a. Arah UX

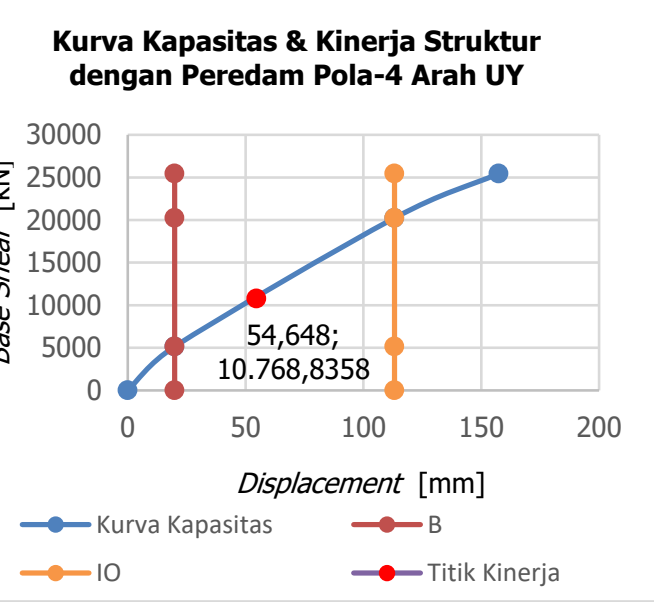

b. Arah UY

Gambar 14. Kurva kapasitas \& kinerja struktur Pola-4

\subsection{Daktilitas}

Nilai daktilitas dari pemodelan kelima struktur dapat dilihat pada Tabel 15 berikut. Pola-4 adalah struktur yang memiliki tingkat daktilitas tertinggi, hal ini terbukti dengan paling banyaknya disipasi energi gempa melalui banyaknya sendi plastis yang terjadi. Secara umum pemasangan FVD pada Pola-2, Pola-3, dan Pola-4 memberikan kinerja struktur yang lebih baik dibandingkan model Tanpa FVD.

Tabel 15. Nilai Daktilitas dari Lima Jenis Model Struktur

\begin{tabular}{cccccc}
\hline Arah & Tanpa FVD & Pola-1 & Pola-2 & Pola-3 & Pola-4 \\
\hline UX & 7,974 & 7,366 & 8,098 & 8,078 & 8,96 \\
\hline UY & 7,051 & 7,911 & 7,911 & 7,911 & 7,911 \\
\hline
\end{tabular}

\section{KESIMPULAN}

1. Kesimpulan terhadap aspek waktu getar.

a. Untuk konfigurasi pemasangan FVD dalam 2 arah sumbu, kinerja FVD akan lebih efektif jika kombinasi lokasinya adalah portal interior arah memanjang dan portal interior arah melintang. Hal ini ditunjukkan dengan durasi waktu getar terpanjang pada kasus Pola-4.

b. Untuk konfigurasi pemasangan FVD dalam 1 arah sumbu, kinerja FVD akan lebih efektif jika lebih banyak sumbu portal yang dipasangi FVD. Hal ini ditunjukkan dengan durasi waktu getar terpanjang pada kasus Pola-2.

2. Kesimpulan terhadap aspek gaya geser dasar.

a. Untuk konfigurasi pemasangan FVD dalam 2 arah sumbu, kinerja FVD akan lebih efektif jika FVD dipasang secara sentris pada sumbu-sumbu portal interior. Hal ini ditunjukkan dengan nilai gaya geser dasar terkecil pada Pola-4 arah $X$.

b. Untuk konfigurasi pemasangan FVD dalam 1 arah sumbu, semakin banyak dipasang FVD pada portal eksterior, maka kinerja tumpuan struktur menjadi lebih baik dalam menahan beban. Hal ini ditunjukkan dengan nilai gaya geser dasar terkecil pada Pola-1.

3. Kesimpulan terhadap aspek simpangan antar tingkat.

Defleksi horizontal arah $X$ akan berkurang jika FVD dipasang pada portal sumbu interior dan sumbu eksterior dengan jumlah FVD pada arah $X$ lebih banyak (kasus Pola-3), dan defleksi horizontal arah $Y$ akan berkurang dengan cukup memasang FVD pada portal eksterior arah $Y$ (kasus Pola-1).

4. Kesimpulan terhadap aspek riwayat keruntuhan struktur.

Pola-1 paling lambat memulai terjadinya sendi plastis dan Pola-4 mendisipasi energi gempa terbesar dibandingkan 3 pola lainnya.

5. Kesimpulan terhadap aspek tingkat kinerja struktur. 
Pemasangan FVD dengan 2 arah sumbu akan lebih baik jika FVD dipasang pada portal interior, (kasus Pola-4) sedangkan untuk kasus pemasangan FVD pada arah melintang sudah cukup baik jika hanya pada portal eksterior (kasus Pola-1).

6. Kesimpulan terhadap aspek daktilitas.

Pola-4 adalah struktur yang memiliki tingkat daktilitas tertinggi, hal ini terbukti dengan paling banyaknya disipasi energi gempa melalui banyaknya sendi plastis yang terjadi.

7. Secara keseluruhan dapat disimpulkan bahwa kinerja struktur menjadi lebih baik setelah menggunakan sistem kontrol pasif pada struktur dan fluid viscous damper memberikan kontribusi gaya redaman dan kekakuan yang cukup baik, pada kasus ini terutama pada Pola-4.

\section{DAFTAR PUSTAKA}

[1] ATC-40. (1996). Seismic Evaluation and Retrofit of Concrete Building Volume 1. California: Applied Technology Council.

[2] Hart, G. C. dan Wong, K. (2000). Structural Dynamics for Structural Engineers. New York: John Wiley \& Sons, Inc.

[3] Haskell, G. dan Lee, D. (2016). Fluid Viscous Damping as an Alternative to Base Isolation. Dipetik Maret 16, 2018, dari http://www.taylordevices.com/fluidviciousdamping.html

[4] Narkhede, D. I. dan Sinha, R. (2012). Shock Vibration Control of Structures Using Fluid Viscous Dampers. 15 WCEE (World Conference on Earthquake Engineering). Dipetik Maret 16, 2018, dari http://www.iitk.ac.in/nicee/wcee/article/WCEE2012_2922.pdf

[5] Ras, A. dan Boumechra, N. (2016). Seismic Energy Dissipation Study of Linear Fluid Viscous Dampers in Steel Structure Design. Alexandria Engineering Journal, __(55), 2821-2832.

[6] Ruan, S. dan Eder, B. (2015). Fluid Viscous Damping for Seismic Energy Protection. Dipetik Maret 16, 2018, dari http://www.structuremag.org/?p=8699

[7] SAP2000. Tutorial SAP2000 versi 14.2.4.

[8] Taylor, D. P. (_). History, Design, and Applications of Fluid Dampers in Structural Engineering. Dipetik September 29, 2017, dari Taylor Device inc.: http://taylordevices.com/papers/history/design.htm

[9] Taylor, D. P. dan Duflot, P. (_). Fluid Viscous Dampers Used for Seismic Energy Dissipation in Structures. Dipetik Maret 16, 2018, dari http://taylordevices.eu/pdfs/seismic\%20applications.pdf 